\title{
Die filosofie kan die teologie help om weg te beweeg van ' $n$ onhistoriese, sinkroniese interpretasie van tekste na ' $n$ historiese, diakroniese interpretasie van tekste
}

\author{
Authors: \\ Pieter H.J. Labuschagne ${ }^{1}$ \\ Jurie H. le Roux ${ }^{1}$ \\ Affiliations: \\ ${ }^{1}$ Department Old Testament \\ Studies, University of \\ Pretoria, South Africa \\ Correspondence to: \\ Pieter Labuschagne \\ Email: \\ pietergo@mweb.co.za \\ Postal address: \\ PO Box 20770, Protea Park \\ 0305, South Africa \\ Dates: \\ Received: 03 Jan. 2012 \\ Accepted: 07 May 2012 \\ Published: 05 July 2012 \\ How to cite this article: \\ Labuschagne, P.H.J. \& Le \\ Roux, J.H., 2012, 'Die filosofie \\ kan die teologie help om weg \\ te beweeg van onhistoriese, \\ sinkroniese interpretasie \\ van tekste na historiese, \\ diakroniese interpretasie van \\ tekste', Verbum et Ecclesia \\ 33(1), Art. \#706, 7 pages. \\ http://dx.doi.org/10.4102/ \\ ve33i1.706
}

(C) 2012. The Authors. Licensee: AOSIS OpenJournals. This work is licensed under the Creative Commons Attribution License.
In the last few decades in South Africa, much emphasis has been placed on unhistorical, synchronistic interpretations of the text of the Old Testament. Very little effort has been made to look into the long historical development of the text from the sources to the present form. Sometimes the advocates of these synchronistic approaches even responded with hostility towards any approach that would, in their words, deny the authority of the text. Their search was for absolute truth, which they believed could be secured by their methods. The uncertainties of historical research were not attractive to them. In this article, we briefly look at Gerhard Von Rad's Traditionsgeschichte [History of Traditions] and Hans-Georg Gadamer's Wirkungsgeschichte [Reception History] and point out that mankind is rooted in history. We thus come to understanding through a process that is tied to our historical horisons. Furthermore, it will become clear that theology and philosophy can help one another in defining the process of understanding.

\section{Inleiding}

Om te verstaan is eie aan die mensdom en die hermeneutiek is met die studie van interpretasie en verstaan gemoeid. Deur die eeue heen is daar op verskillende maniere met hierdie onderwerp omgegaan en dikwels is verskillende benaderings in die interpretasie van tekste gevolg. Sedert die ontwikkeling van natuurwetenskaplike metodes het die druk op die hermeneutiek toegeneem om ook op 'n meer wetenskaplike manier te werk te gaan. Dit het tot velerlei metodes van teksinterpretasie aanleiding gegee, wat ongelukkig daartoe gelei het dat historiese benaderings tot verstaan dikwels in die slag gebly het. Al hoe meer metodes wat uitsluitlik op die finale teks van die Bybel fokus, is ontwikkel. ${ }^{1}$ Hierdie metodes gaan dikwels op 'n sinkroniese manier met die teks om, sonder om vrae oor die groei van die teks te vra. Gevolglik is verstaan verlaag tot 'n objek wat versteek lê onder die oppervlak van die finale teks en wat deur die korrekte toepassing van metodes ontdek kon word. Dit gee aanleiding daartoe dat die proses-karakter van Verstehen [verstaan] verlore gaan. Die interaksie tussen die teks en die interpreteerder, wat essensieel is tot verstaan, kom dan nie tot sy reg nie. Ons moet weer leer dat Verstehen 'n werkwoord is; dit is ' $n$ aktiwiteit, 'n ervaring, 'n proses. Met verwysing na Gerhard Von Rad se Traditionsgeschichte en Hans-Georg Gadamer se Wirkungsgeschichte gaan ons aantoon hoe die teologie en die filosofie mekaar kan help met hierdie proses van verstaan.

\section{Metodes help ons nie}

In die laaste paar dekades het Bybelinterpretasie in Suid-Afrika gesentreer rondom metodes wat op die finale teks konsentreer. Voorstanders van hierdie metodes ignoreer die moeilike probleemvrae in die teks en ontken enige spanning in die teks. Hulle staan histories-kritiese eksegese teë en fokus net op ' $n$ sinkroniese benadering tot die teks (Groenewald 2007:1024). Vir hulle is die teks die enigste betroubare bron vir interpretasie. Dit is ' $n$ baie naïewe seining, wat die teks interpreteer sonder om rekening te hou met die outeur se bedoeling of die historiese totstandkomingsproses van die teks. Le Roux (1992) sê:

The text is not a timeless object containing eternal truths which was written during one sitting. It originated in specific circumstances and is the product of its time. A historical investigation therefore focuses on the circumstances and the age in which it originates, as well as that in which it is transmitted. (p. 14)

Groenewald (2007:1028) sluit hierby aan: 'Therefore, it can be deduced that synchronic analysis without diachronic input only touches the textual surface'.

Die struktuuranalise het ' $n$ baie gewilde metode geword en verskeie boeke is oor die onderwerp geskryf. Dit is onmoontlik om 'n volledige lys te maak, maar ons kan 'n paar voorbeelde noem. ${ }^{2}$ 1.Met finale teks bedoel ons nie dat teks-kritiese arbeid afgesluit is en ' $n$ finale teks in die absolute sin bestaan nie. Ons gebruik die term slegs om te verwys na die Bybelteks wat tans voor ons lê en wat sommige navorsers gebruik sonder om ag te slaan op die tekshistoriese ontwikkeling en agtergrond daarvan. 
Nie net vakgenote nie, maar selfs gemeentelede is opgelei in die metode en die toetsbaarheid van die resultate sowel as die uniformiteit wat 'n grammatikale analise van die teks oplewer, het baie aansien aan hierdie metode verleen. Een voorbeeld hiervan is Veritas College International ${ }^{3}$, wat tans in nagenoeg 30 lande werk en 'n jaarlikse studentetal van 10000 het. Die hele program van vier Modules is gegrond op die boek How to Interpret the Bible: a do-it-yourself manual deur dr Bennie Wolvaardt, wat self 'n student van die struktuuranalise in Suid-Afrika was.

Sonder om die waarde van ' $n$ metode soos die bogenoemde te ontken, moet daar egter op een van die belangrikste leemtes van teks-immanente metodes gewys word: Hierdie metodes konsentreer eksklusief op die teks soos dit voor ons lê. Die interpreteerder en hul metode neem totale beheer oor die teks en teksinterpretasie word 'n monoloog. Die teks word nie toegelaat om tot die interpreteerder te spreek of om sigself te verdedig nie. Die klem val op die deeglike en korrekte toepassing van ' $n$ metode. Die metode identifiseer strukture wat in die grammatika van die teks vasgelê is en die interpreerder maak haar ofsy toepassings aan die hand daarvan. Een van die grootste probleme met so 'n benadering is dat dit belangrike historiese aspekte van verstaan buite rekening laat.

Die Bybelwetenskap het mettertyd gegroei tot 'n selfstandige studieveld wat al hoe meer berus het op metodes wat deur Bybelwetenskaplikes self geslyp is. Daarom staan die teologie soms apaties teenoor ander vakdissiplines en sien nie die voordeel daarvan om by ander geesteswetenskappe te leer nie. Voeg hierby die klem wat die Reformasie geplaas het op Sola Scriptura en 'n mens verstaan die apatiese houding wat ingeneem word. Die teks word gesien as die finale gesag en enige iets wat hierdie gesag bevraagteken of moontlik kan ondermyn, moet summier verwerp word. Die geloof in die Bybel as die hoogste gesag maak dit vir diegene ondenkbaar dat ' $n$ buite-Bybelse dissipline soos die filosofie ' $n$ bydrae tot die verstaan van die Bybel kan lewer. Ons weet egter dat daar groot waarde is in vakke soos die filosofie, die geskiedenis, volkekunde, die argeologie en dies meer om die interpreteerder van die Bybel te help om te verstaan van wat gelees word (Loader 1986:128-142).

\section{Die interafhanklikheid van die filosofie en die teologie}

Jean Grondin (2002:97-101) het 'n besondere bydrae gelewer op die gebied van die interafhanklikheid tussen die teologie

2.Blommaert, J., 2005, Discourse, Cambridge University Press, Cambridge. Brown, G \& George Y., 1983, Discourse Analysis, Cambridge University Press, Cambridge. Gee, J.P., 2005, An Introduction to Discourse Analysis: Theory and Method, Routledge, London.

Harris, Z.S., 1981, Papers on Syntax, Synthese Language Library, 14, D. Reidel, Dordrecht.

Harris, Z.S., 1991, A Theory of Language and Information: A mathematical approach, Clarendon Press, Oxford.

Jaworski, A. \& Coupland, N. (eds.), 1999, The Discourse Reader, Routledge, London Johnstone, B., 2002, Discourse analysis, Blackwell, Oxford.

Longacre, R.E., 1996, The grammar of discourse, Plenum Press, New York.

Renkema, J., 2004, Introduction to discourse studies, Benjamins, Amsterdam.

Schiffrin, D., Deborah, T. \& Hamilton, H.E. (eds.), 2001, Handbook of Discourse

Schiffrin, D., Deborah, T. \&

Analysis, Blackwell, Oxford.

language, Blackwell, Oxford.
labs,

3.Vir meer inligting sien: www.veritascollege.org en die filosofie toe hy oor die New Proximity between Theology and Philosophy geskryf het. In sy artikel verwys hy na Boek E van Aristoteles se Metafisika. Sedert hierdie werk van Aristoteles verskyn het, was die band tussen die teologie en die filosofie baie sterk. Aristoteles:

set the framework for a relation that would obtain for two millennia: philosophy, as a quest for wisdom, is a search for the causes, the ultimate cause or the beginnings (archai) of things, that can be suspected in the realm of the divine. (Grondin 2002:97)

Volgens Aristoteles vervul die teologie dus die rol van proté philosophia: 'n eerste filosofie. Aristoteles brei hierdie noue verhouding tussen die teologie en die filosofie verder uit deur te wys op die feit dat die goddelike op nadenke berus: 'indeed in the thinking of thinking (noesis noeseos)'. (Grondin 2002:97). Vir hom was die goddelike die sfeer van die suiwer rede. Hans Krämer het hierdie konsep Geistesmetaphysik genoem, wat van die aanname uitgaan dat die goddelike rasioneel van aard is en dat dit met ander woorde verstaan kan word deur ons intellek, wanneer dit tot sy hoogste potensiaal verhef word. Soos Grondin (2002) dit stel:

The proximity between philosophy and theology could not be closer, nor more rational: theology is a science $(\log o s)$ of the divine (theos), and philosophy is a quest for a wisdom concerning the first causes, which can be found in the divine. (pp. 97-101)

\section{Rede of openbaring?}

Grondin wys daarop dat ' $n$ verandering ingetree het met die ontwikkeling van ' $n$ teologie wat nie op rede gebou is nie, maar op openbaring. Dit het spanning tussen die teologie en die filosofie teweeg gebring omdat die filosofie nie soos in die geval van die teologie op 'n spesiale openbaring aanspraak kan maak nie. Dit is immers ondenkbaar dat enige mens met hul beperkte intellektuele vermoë werklik daarop aanspraak kan maak om die goddelike te ken. Waar beskikbaar, moet die teologie op ' $n$ openbaring uit die Bybel berus, maar ook op ' $n$ openbaring wat ons in die kerk en die tradisie terugvind (Grondin 2002). Hierdie verskil tussen die teologie en die filosofie lei tot spanning en selfs konflik tussen die twee dissiplines. Iemand soos Karl Barth het hierdie konflik in ons eeu volgehou: 'He was widely accused of succumbing to a "positivism of Revelation"' (Grondin 2002:98).

Die teologie was dus bo die filosofie verhewe omdat die teologie nie net die rede gehad het om op terug te val nie, maar ook die openbaring. Hoe het die filosofie hierdie spanning tussen die twee dissiplines gesien? Grondin verwys na Paulus se Grieks-filosofiese gehoor in Athene en hoe sy aanspraak op direkte openbaring reeds vir hulle nie aanvaarbaar was nie. Sonder om op die volledige verhouding tussen die filosofie en die teologie deur die eeue in te gaan, is dit voldoende om op te merk dat die filosofie in die rede geanker was en die teologie in openbaring, 'yet, they still aimed at the same sort of wisdom about matters of "ultimate concern" that are not addressed by other sciences' (Grondin 2002). Die spanning tussen die twee vakdissiplines het verseker dat die beste filosowe altyd ook in die teologie geïnteresseerd was. Grondin (2002) sê die volgende: 
Augustin (sic), Anselm of Canterbury, Thomas, Occam, Suarez, Descartes, Spinoza, Leibniz, Kant, Schleiermacher, Fichte, Schelling, Hegel, Feuerbach were all outstanding philosophers, but also theologians of the highest order, if not first and foremost. (n.p.)

Grondin (2002) verwys ook na ander Duitse teoloë, naamlik Kant, Nietzsche, Dilthey en Martin Heidegger. Volgens hom was Heidegger (wat sy loopbaan as 'n kandidaat vir die priesterdom begin het) waarskynlik een van die laaste groot filosowe wat met die teologie vertroud was. Hy het baie kontak gehad met Rudolf Bultmann en het self ook oor die teologie geskryf:

In a well-known lecture of 1927 on 'Theology and Phenomenology' he gave a thorough, yet scholastic sounding account of the relations between philosophy and theology...philosophy is a science of Being, whereas theology is a 'positive' science, that deals with the 'ontic' phenomenon of Christlichkeit or 'Christianhood'. (Grondin 2002:n.p.)

\section{Die sensitiewe verhouding tussen die teologie en die filosofie}

Grondin (2002) wys daarop dat die filosofie ná Heidegger grootliks on-teologies geword het, met enkele klein uitsonderings, soos Ernst Bloch, Hans Jonas, Paul Ricoeur en Hans-Georg Gadamer. Vir die grootste gedeelte het filosowe opgehou om die debat binne die teologie te volg:

This is, of course, evident for analytical philosophy, that is widespread in the English-speaking world and that is most allergic to theology and any kind of discourse that transcends the realm of the empirically verifiable. This is true of currents like existentialism, structuralism, and post-structuralism, that have been the most influential. (Grondin 2002:97-101)

Grondin (2002:99) sê dat filosowe gedurende die laaste 50 jaar meer geïnteresseerd was in "language..., for the predicament of the godless individual, for social and political structures than they were for theological matters'. Enige iemand wat gedurende hierdie tyd na die teologie verwys het, is met suspisie bejeën. In onlangse tye het hierdie houding stadig begin verander en sien Grondin by filosowe weer 'n groeiende belangstelling in die teologie. Hy verwys na iemand soos Emmanuel Levinas, wat sterk op sy eie Joodse agtergrond gesteun het:

to call philosophy back to its own questions and the urgency of the ethical, that he described in very vertical, even theological terms, when he spoke, for instance, of the epiphany of the Other' (Grondin 2002:n.p.)

Hy verwys ook na Franse geleerdes wat begin het om in hulle eie Christelike tradisie fenomene te ondersoek wat vroeër geïgnoreer is: 'This return was so striking that Dominique Janicaud spoke of a "theological" turn of French phenomenology' (Janicaud 1991). Selfs Jacques Derrida het saam met Gianni Vattimo (Vattimo \& Derrida 2001) 'n publikasie oor godsdiens uitgegee. Later het Derrida 'n volgende werk gepubliseer wat oor geloof en kennis gehandel het (Derrida 2001).

Gianni Vattimo se bydrae is van groot belang. Hy is een van die vernaamste verteenwoordigers van die postmoderne redevoering. Vir hom wentel die postmodernisme om 'n bewuswording van die interpretatiewe (of hermeneutiese) karakter van die wêreld. Aangesien ons binne 'n interpretatiewe werklikheid lewe, moet ons leer om met mekaar oor die weg te kom; ons moet 'n meer beskeie en nederige denkwyse aanneem. Vir Vattimo is die Christendom juis die bron waaruit hierdie nuwe verdraagsaamheid vloei. Hy sê die rede hiervoor is die Christendom se aard van liefde, kenosis en versoening. Grondin (2002) meen:

Vattimo's impressive, albeit at first paradoxical sounding thesis is that it is the Nietzschean proclamation of the death of God and Heidegger's conception about the end of metaphysics that can help us rediscover the Christian Experience of faith. The god that is dead is only the god of metaphysics, understood as an ultimate and necessary foundation of the objective universe. (n.p.)

\section{Die einde van absolute, objektiewe kennis}

Vattimo sê dit is hierdie god van die metafisika wat millitante ateïste probeer ontken, maar hulle het dit probeer doen met dieselfde tipe objektiewe en rigiede sekerheid waarmee die metafisika en die objektiewe redevoering werk. Die ateïsme roem volgens hom daarop om absolute en sekere kennis van die wêreld te hê. Vattimo stel dit egter baie duidelik dat daar nie so iets bestaan nie. Hy gaan selfs verder en sê:

The overcoming of this horizon of metaphysics could permit us to reacquaint ourselves with the God of the Bible and its sense of historicity, event, contingency, that would correspond to our 'post-modern' condition. (Grondin 2002:100)

Vir hom is die Bybel nie ' $n$ rasionele boek nie en die Bybel self maak nie die aanname om absolute kennis van die wêreld te bevat nie. Die Bybel sentreer eerder rondom 'n historiese boodskap, wat (net soos ons eie kennis) gebaseer is op wat ons gehoor het en waarvolgens ons lewe.

Bydraes soos bogenoemde het die teologie en die filosofie nader aan mekaar gebring. Ernst Jünger (1999), die Duitse skrywer, het opgemerk dat die verdwyning van godsdiens 'n baie onlangse verwikkeling is, en baie beperk is wat tyd en ruimte betref. Grondin wys daarop dat van die grootste sosiale probleme wat tans in die wêreld bestaan, godsdienstige ondertone het. Hy verwys veral na die onlangse konflik tussen Islam en die verwesterste, Joods-Christelike wêreld. Die filosofie kan nie hierdie dilemmas sonder die hulp van die teologie aanpak nie. Nogmaals Grondin (2002):

The ultimate questions remain, and have always been present. It was indeed hybris to believe intellectuals could wipe away the religious heritage of mankind and replace it with demagogic substitutes. Philosophy can thus open itself anew to what religions and theologians have to say, as always did the best traditions of philosophy. (p. 101)

Bogenoemde hou natuurlik ook gevolge vir die teologie in. Daar is ' $n$ wedersydse invloed tussen die filosofie en die teologie. Net soos die filosofie weer na die teologie moet terugkeer, moet die teologie ook 'n openheid vir die invloed van die filosofie behou. Die openbaring wat eie is aan die teologie, is nie ' $n$ rede tot meerderwaardigheid nie, want absolute en objektiewe waarhede bestaan ook nie in die teologie nie. Sinkroniese, teks-immanente metodes 
het probeer om by vaste waarhede uit te kom en dit as absolute waarheid te kanoniseer. Net soos in die geval van die filosofie, het die teologie egter ook nou by die kruispad gekom wat die soeke na waarheid betref. Ook die teoloë besef nou dat absolute waarheid nie bestaan nie. Daarom het Vattimo gesê die filosofie moet die objektiewe ideaal van die metafisika oorkom en terugkeer na God en die Bybel. Wat hy hier sê is belangrik: Die Bybel is nie 'n rasionele boek wat op absolute waarheid aanspraak maak nie, en alhoewel dit 'n geskiedenisboek is, is hierdie geskiedenis op ervaring, interpretasie en verkondiging gebou.

Dit is waarna Gerhard Von Rad (1967) as Heilsgeschichte verwys het: geskiedenis wat rondom die heilsdade van Jahwe in verhouding tot sy volk sentreer:

Here everything is shaped by faith; even the association of the events into a grand path of salvation is not merely historical record, but is in itself already an acknowledgement of the leadership of God. This history of the traditions before they reach their final form in written sources comprises an incalculable diversified chapter of Israel's theology. In general, even the simplest fusion of two originally independent units of tradition was in itself already a process of theological interpretation. (pp. 3-4)

Die doel van die Ou Testament was nooit om abstrakte geskiedenis te wees nie, maar bevat mense se historiesgebonde ervaringe en nadenke oor hulle verhouding met Jahwe. Dit is meer ' $n$ heilsgeskiedenis as 'n poging tot ' $n$ objektiewe, feitelike geskiedenis.

\section{Gerhard Von Rad en Hans-Georg Gadamer}

Kan enige intieme verhouding tussen die teologie en die filosofie slaag? Die beste manier om hierdie vraag te antwoord, is deur na 'n voorbeeld te kyk. Gerhard Von Rad was een van die $\mathrm{Ou}$ Testamentici wat die grootste impak op die studie van die Ou Testament gehad het. Crenshaw (1978:15) beklemtoon sy invloed deur te praat van die Ou Testament-wetenskap vóór en ná Von Rad. Von Rad se Theologie des Alten Testaments in twee volumes was ' $\mathrm{n}$ keerpunt in die verstaan van die Ou Testament en dit het die Ou Testamentiese-wetenskap in 'n nuwe rigting gestuur. Dieselfde kan van Hans-Georg Gadamer se hermeneutiese filosofie gesê word: Hy was een van die prominentste denkers van die afgelope eeu en sy bekende werk Wahrheit und Methode het ' $\mathrm{n}$ nuwe maatstaf geword om die proses van historiese verstaan te definieer. Alhoewel hierdie twee grootse figure nie saam gewerk het nie en skynbaar geen direkte invloed op mekaar gehad het nie, was hulle kinders van hulle tyd en het hulle in die era van die opbloei van geskiedenis en geskiedskrywing geleef. Von Rad, as teoloog, benader die $\mathrm{Ou}$ Testament vanuit die oogpunt van die historiese oordragproses van tradisies, wat gelei het tot die finale gestalte van die Ou Testament (Traditionsgeschichte). Gadamer, as filosoof, benader verstaan vanuit die oogpunt van die herhalende proses van historiese herinterpretasie van die teks (Wirkungsgeschichte). Wat Von Rad en Gadamer saambind, is hulle fokus of die gemeenskaplike grond van die geskiedenis en die mens se historiese geworpenheid in hierdie wêreld.

\section{Traditionsgeschichte}

Alhoewel die historiese kritiek al reeds in die 17de eeu begin het, het dit in die 19de en 20ste eeu baie populêr geword en het dit hoogty gevier. Alle tekste is met hierdie benadering gelees. Die klem het meer en meer begin val op dit wat in tekste as histories betroubaar beskou kon word en die historiese kritiek het probeer om die historiese minimum van ' $n$ teks te ontdek. Alles wat nie as histories betroubaar bewys kon word nie, is van die teks afgestroop. Ten spyte van opstandigheid en vyandigheid teenoor die resultate van die historiese kritiek, het Von Rad hom nie laat afskrik nie. Hy het nie probeer om teen die stroom van die historiese kritiek op te swem nie, maar het eerder die beginsels daarvan gebruik om die Ou Testament beter te verstaan. In sy lees van die $\mathrm{Ou}$ Testament het dit vir hom duidelik geword dat die teks voor hom nie 'n eenvoudige ontstaan gehad het nie. Hy het probeer om histories terug te beweeg in die geskiedenis van Israel en te vra hoe die teks tot stand gekom het. Hy wou weet hoe verskillende bronne, wat iemand soos Welhausen reeds uitgewys het, saamgevoeg is en gegroei het tot wat ons vandag ken as die Pentateug (Le Roux 1995:41, 43). In hierdie proses het Von Rad die credo ontdek, wat vir hom gedien het as die basiese bousteen waaruit die ganse Ou Testament gegroei het. Hy het drie weergawes van die credo geïdentifiseer, naamlik Deuteronomium 26:5-9; Deuteronomium 6:20-24 en Josua 24. Die tradisies van Israel het vir hom begin uitstaan as boustene wat herhaaldelik herinterpreteer en saamgevoeg is tot dit uiteindelik tot die huidige teks van die Ou Testament gegroei het (Von Rad 1967:3-5). In die woorde van Le Roux (2005):

Die aantreklikheid van Von Rad se werkswyse lê juis daarin dat dit ons help om die kritiese wetenskap te aanvaar, maar ook nog teologies besig te wees; om die historiese minimum van die $\mathrm{Ou}$ Testament te herken, maar ook na 'n teologiese maksimum te streef; om die historiese kritiek se geweldige kritiese impak te besef, maar dit nogtans as 'n onontbeerlike stuk eksegetiese gereedskap te beskou; om die insigte van die kritiese geskiedswetenskap te aanvaar en selfs te gebruik, en nog steeds teologies met die Ou Testament om te gaan. (p. 5)

Ons moet besef dat Von Rad se teologie op die geskiedenis gebou is: Hy het deur historiese interpretasie die teks voor hom probeer verstaan. Hy het aangedui hoe iets soos die basiese credo in elke nuwe generasie herinterpreteer is en op hulle eie omstandighede van toepassing gemaak is (Von Rad 1967:311). Israel het vasgehou aan 'n basiese geloofsbelydenis wat van een geslag na die volgende oorgedra is. Le Roux (2001) vat dit as volg saam:

Hierop het Von Rad geantwoord dat iets soos 'bruta facta' nie bestaan nie en dat geskiedenis slegs in interpretasie voortleef. ' $n$ Gebeurtenis in Israel se verlede en die interpretasie daarvan in 'n daaropvolgende era is onafskeidbaar van mekaar. (p. 153)

Namate omstandighede verander het en hulle nuwe uitdagings in die gesig gestaar het, moes hulle hulleself afvra wat die credo vir hulle eie konteks beteken het. Die gevolg 
was dan ' $n$ herinterpretasie van hulle geloof in ' $n$ nuwe, spesifieke historiese situasie. Brueggeman (2001) stel dit soos volg:

Subsequent generations have access not to the 'mighty deed', but to the attestation of the 'mighty deed'. It is very well, subsequently, to take the canonical form of recital as 'revelation', but it is always revelation-as-testimony. The point is fundamental to Von Rad. (p. xvi)

Daar was nie ' $n$ breuk tussen hierdie verskillende historiese interpretasies nie, maar die een het uit die vorige voortgevloei. Die geskiedenis, wat soos ' $n$ goue draad deur die $\mathrm{Ou}$ Testament loop, bind hierdie verskillende interpretasies saam. Rofé (1999) sê:

Von Rad hypothesized that the source of the literary form of the Hexateuch (the Pentateuch and the book of Joshua) lay in the ancient Israelite cult. There, in the confessions of believers, or the declarations of sanctuary functionaries, the history of Israel was surveyed from the promise to the Patriarchs, through the descent into Egypt, the Exodus, the journey in the wilderness, and possession of the land. (pp. 95-96)

Von Rad was sensitief vir die historiese ontwikkeling van die $\mathrm{Ou}$ Testament en hierdie benadering van hom help ons om die teks voor ons te verstaan. Die geheim van Von Rad se benadering is dat die geskiedenis ' $n$ brug geword het wat ons aan die Ou Testament verbind. Deur op die historiese ontwikkeling van die Ou Testament ag te slaan, word die interpreteerder bewus van die rol wat die geskiedenis speel in die proses van verstaan (Le Roux 1995:58). Israel het nooit ten doel gehad om ' $n$ abstrakte geskiedenis van hulle eie volk of van hulle wêreld in die algemeen te skryf nie; wat hulle neergepen het, was hulle eietydse interpretasie van dit wat Jahwe besig was om in hulle midde te doen (Von Rad 1967:xx-xxiv). In Von Rad (2001) se eie woorde:

This Deuteronomistic theology of history was the first which clearly formulated the phenomenon of saving history, that is, of a course of history which was shaped and led to a fulfilment by a word of judgment and salvation continually injected into it. (p. 344)

Elke vers wat ons in die Ou Testament lees, was die antwoord op ' $n$ vraag wat in 'n spesifieke historiese situasie gevra is. Die basis vir Israel se herinterpretasies van vroeëre materiaal is gegrond in hulle behoefte om uit God se handelinge binne hulle eie historiese konteks sin te maak (Von Rad 1967:95). Hulle het nooit doelbewus probeer om die tradisies of die credo te ontwikkel en te verander nie. Dit was ' $\mathrm{n}$ normale verloop van die lewe; dit was vir hulle ' $n$ natuurlike proses om dit wat vroeër gebeur het na hulle eie tyd deur te trek. Daarom staan die verskillende tradisies en oorlewerings in die Ou Testament nie los van mekaar of selfs téénoor mekaar nie, maar vloei die een uit die ander voort. Wat in een historiese situasie gebeur het, was onlosmaaklik verbonde aan dit wat in ' $n$ volgende historiese situasie gebeur het. Elke generasie het op die verhouding tussen Jahwe en sy volk voortgebou. Elke generasie het wat histories aan hulle oorgelewer is, nuut geïnterpreteer op ' $n$ manier wat in hulle eie konteks sin gemaak het. Daarom is die oorlewerings waarna Von Rad verwys nie die oorvertel van abstrakte historiese feite, wat onveranderd van een generasie tot die volgende oorgedra is nie; nee, hierdie oorlewerings was persoonlike interpretasies wat op teologiese gronde gevorm is. Dit was Israel se histories-gebonde interpretasies van Jahwe se handelinge in hulle midde. Dit was voorwaar episodes van die Heilsgeschichte van Israel as volk. Von Rad (1967) vat dit treffend saam:

Hebrew thinking is thinking in historical traditions; that is, its main concern is with the proper combination of traditions and their theological interpretation, and in the process historical grouping always takes precedence over intellectual and theological grouping. (p. 116)

Die klem in die tradisiegeskiedenis van die Ou Testament het nooit net geval op wat die teks in die verlede beteken het nie, maar elke generasie het gevra wat die teks in hulle eie historiese situasie beteken (Von Rad 1967:290). So ontstaan daar dan ' $n$ historiese band tussen die verskillende tradisies: Dit het alles te make gehad met Israel se verstaan van Jahwe se heilshandelinge in hulle midde. Von Rad (2005) huldig die volgende mening:

Ancient and often very scattered traditions are brought together around one central co-ordinating conception, and by some massive tour de force achieve literary status. In Israel, where this applies almost exclusively to religious deposits formerly bound up with the cultus, the process penetrated to an unusual depth. (p. 36)

Om saam te vat: Von Rad se Traditionsgeschichte maak ons bewus van die oorlewering en groei van die teks van die $\mathrm{Ou}$ Testament vanaf die basiese bronne tot wat vandag voor ons in die teks lê. Die motivering vir hierdie oorlewering van een geslag na die volgende was nie om abstrakte, historiese feite te bewaar en weer te gee nie, maar om uit hulle eie persoonlike ervaring van Jahwe in hulle unieke historiese situasies sin te maak (Le Roux 1995:60). Wat op die bladsye van die Ou Testament oorgedra word, is die Heilsgeschichte van Israel: hulle histories-gebonde geloofsbelydenisse van Jahwe se handelinge in hulle midde. Die historiese geworpenheid van elke individu en elke generasie in Israel het tot hulle historiese interpretasie en herinterpretasie van vroeëre materiaal gelei. Deur van hierdie oordrag van tradisies bewus te word, het Von Rad gehelp om die Ou Testament te verstaan teen die konteks en geskiedenis waarbinne dit ontstaan het.

Hy het dus die rol raakgesien wat die geskiedenis in die ontwikkeling en verstaan van die Ou Testament gespeel het. Sonder hierdie historiese sensitiwiteit kan die teks nie verstaan word nie. Wat Von Rad vir ons belangrik maak, is nie enige metode wat hy bevorder het nie, maar die klem wat hy op die geskiedenis geplaas het (Von Rad 1967:288-289). Hy het besef die mens is ' $n$ historiese wese, wat slegs in die lig van die historiese sinvol kan verstaan. Niks ontstaan buite hierdie historiese realiteit nie; die mens is ' $n$ historiese wese en in die konteks van sy of haar historiese geworpenheid, verstaan die individu. Alhoewel Von Rad dit nooit self pertinent gesê het nie, maak sy bydrae dit duidelik dat die mens ' $n$ baie belangrike rol speel omdat die mens ' $n$ bydrae maak tot verstaan: dit is immers die mens self wat die herinterpretasie doen.

\section{Wirkungsgeschichte}

'n Bestudering van Gadamer se Wirkungsgeschichte lewer soortgelyke resultate op. Uit die staanspoor moet ons egter 
besef dat hy met ' $n$ ander benadering na die teks gekom het as Von Rad: Hy was nie sodanig in die ontstaansgeskiedenis van die teks geïnteresseerd nie, maar het met sy Wirkungsgeschichte verwys na die historiese herinterpretasie van die teks wat voor ons lê. So het hy byvoorbeeld die konsep van tydsafstand op die tafel geplaas (Gadamer 1989:291-299). Andere het hierdie tydsafstand beskou as iets wat die moderne interpreteerder van die teks skei en verstaan bemoeilik. Dit is juis vanweë die afstand tussen die teks en die interpreteerder dat daar in die vroeë hermeneutiek tot 'n drieledige onderskeid gekom is: eksegese, interpretasie, toepassing. Die klem het geval op wat die teks beteken hét, hoe dit verstaan moet word en hoe dit dan in 'n nuwe situasie toegepas moet word. Die teks en die moderne interpreteerder is beskou as ver verwyder van mekaar en daar kon nooit ' $n$ ware nabyheid tussen die twee tot stand kom nie. Die afstand is beskou as ' $n$ aaklige afgrond wat skeiding bring.

Gadamer neem die tydsafstand ter harte en voer aan dat ons nie hierdie afgrond hoef te vrees nie. Dit is nie ' $n$ afgrond wat skeiding bring nie; dit is eerder 'n kloof gevul met potensiaal. Die potensiaal lê in die historiese herinterpretasies (of dan die Wirkungsgschichte) wat hierdie kloof vul. Net soos Von Rad wat na elke nuwe generasie verwys het wat die tradisies in hulle eie konteks nuut interpreteer het, verwys Gadamer (1989:299-306) na die horisonne van elke mens. Hy maak dit duidelik dat elke mens binne ' $\mathrm{n}$ histories-bepaalde horison leef: Wie hul is en wat hul glo, word alles deur hulo horison beïnvloed en andersom. Sedert die mens se geboorte bevind die individu hulself in ' $n$ historiese realiteit, waar hul van historiese invloede afhanklik is. Die historiese Dasein van elke mens is ' $n$ realiteit waarmee rekening gehou moet word (Gadamer 1989:244). Geskiedenis self het geen begin of einde nie, maar gaan voort deur die eeue en elke mens vorm deel van hierdie historiese realiteit. Die mens het nie net 'n invloed op die geskiedenis nie, maar die geskiedenis het ' $n$ invloed op die mens; die geskiedenis vorm die mens.

Wat die Wirkungsgeschichte ons bied, is die vermoë om tussen historiese horisonne te beweeg. Dit word moontlik gemaak deur die feit dat daar nie geslote horisonne bestaan nie, maar dat elke horison ' $\mathrm{n}$ openheid het wat histories bepaald is. Wanneer Gadamer (1989:398) van 'n versmelting van horisonne praat, het hy juis in gedagte dat twee unieke horisonne met mekaar in gesprek tree. Let egter daarop dat net soos die mens in die hede se horison nie geslote is nie (omdat dit voortdurend groei en aanpassings ondergaan), is die horisonne uit die verlede geslote. In 'n sekere mate is beide horisonne bloot verskillende tydshistoriese manifestasies van menswees.

Elke interpretasie wat deur die eeue gemaak word, bou voort op ' $n$ ander interpretasie en word deur ander interpretasies beïnvloed. Die moderne leser laat toe dat sy eie horison met horisonne uit die verlede in interaksie tree. Dit word 'n spel van verstaan, waar die interpreteerder sigself oorgee aan ' $n$ proses waar hul en die teks in 'n interaksie betrokke raak (Weinsheimer 1991:13-14). Dit is nie die interpreteerder of die teks wat in die fokuspunt van hierdie spel staan nie, maar die spel self: die proses, die gebeure wat aan die afspeel is. Net soos in Von Rad se Traditionsgeschichte, waar elke nuwe generasie uit hulle eie situasie probeer sin mak, gebeur dit ook in Gadamer se spel: die speler (interpreteerder) speel 'n aktiewe rol in die soeke na verstaan. Verstaan kan nie sonder die interpreteerder plaasvind nie, want verstaan is ' $n$ gebeure wat histories bepaald is. Die klem vir Gadamer val nooit op absolute verstaan nie, maar op 'n proses van totverstaan-kom (Gadamer 1989:223-227). Waar metodes na sekerheid streef, bring historiese interpretasie onsekerheid en ontnugtering. Ons kan nooit volledig weet wat iets beteken nie: nie in die verlede of die hede nie. Verstaan is vloeibaar en dinamies en ontwyk ons telkens, net sodra ons dink ons het dit gesnap.

\section{Historiese verstaan is nie maklik nie}

Sowel Von Rad as Gadamer het hierdie moeilike pad van historiese verstaan gestap en hulle beywer vir historiese verstaan, wat 'n voortdurende proses is. Von Rad (1967:108) het verwys na die historiese minimum, waaruit hy gepoog het om die teologiese maksimum af te lei. Die spore van die geskiedenis lê dof in die stof van die verlede en die mens kan nooit ' $n$ volledige beeld van hierdie geskiedenis hê nie. Daar moet gewerk word met die minimum wat ons wel het en waaruit ons die spel van verstaan betree. So word verstaan dan 'n historiese proses. Die mens kan nie anders as om op so 'n historiese wyse te verstaan nie.

Gadamer (1989:546-547) wil die interpreteerder uitdaag tot 'n dialoog met die teks. Die teks op sigself lê as 'n dooie dokument voor ons, wat verwyder is van sy eie historiese wortels. Die interpreteerder benader hierdie teks aan die hand van hul eie voorverstaan en vooroordele, wat histories bepaald is. Wanneer die interpreteerder egter die teks in 'n tweegesprek betrek, word die teks in staat gestel om tot spreke te kom (Gadamer 1989:178-185). Sowel die teks as die interpreteerder neem aan hierdie dialoog deel en beïnvloed mekaar en roep mekaar tot orde. Omdat beide histories bepaald is, bestaan die moontlikheid tot kommunikasie.

\section{Raakpunte tussen Von Rad en Gadamer}

Sonder om verder op die detail van Traditionsgechichte en Wirkungsgeschichte in te gaan, is dit reeds duidelik dat daar baie raakpunte tussen Von Rad en Gadamer se benaderings tot verstaan bestaan. Beide het die geskiedenis beskou as die medium om tot verstaan te kom. Die mens is histories bepaald en deur konstante interpretasie en reïnterpretasie kom die mens tot verstaan. Verstaan is nie 'n abstrakte konsep wat êrens in die teks verskuil lê en net deur 'n objektiewe metode ontdek moet word nie; verstaan is deel van die mens se wese; verstaan is die wyse waarop die mens bestaan (Gadamer 1989:184-195). Verstaan is 'n oneindige proses waaraan elke mens aktief deelneem.

Von Rad het gesê die Ou Testament is Heilsgeschichte, 'n geloofsbelydenis van Jahwe se ingrype in Israel se 
geskiedenis; 'n verhouding wat deur Jahwe se historiese dade tot stand gekom het. Dit is ' $n$ beperkte spreke in 'n spesifieke historiese situasie. Gadamer (1989:418-426) beskou die teks ook as 'n beperkte vorm van spreke. Die innerlike woord van die mens kan nooit ten volle in gekrewe taal omgesit word nie en daarom is elke poging tot opskrifstelling van die innerlike woord ' $n$ inperking van kommunikasie. Deur die spel tussen die interpreteerder en die teks word daar gesoek na die innerlike woord wat agter die teks lê. Dit is wat Von Rad ook probeer identifiseer het met sy credo en die herinterpretasie daarvan deur die eeue.

\section{Gevolgtrekking}

Die teologie (in Von Rad se geval) en die filosofie (in Gadamer se geval) het albei tot ' $n$ historiese verstaan van antieke tekste gelei. Albei het tot die slotsom gekom dat die mens 'n historiese wese is wat nie van sy orhaar bestaanshorison losgemaak kan word nie (Gadamer 1989:299-306). Ware verstaan is ' $n$ proses waaraan die mens as historiese wese aktief deelneem; deur interpretasie en herinterpretasie kom die mens tot verstaan. Hierdie verstaan kan nie in ' $n$ absolute sin verkry word nie, maar groei saam met die mens deur hul historiese reis deur die lewe. Interpretasie kan daarom nie namens iemand anders gedoen word nie; dit is 'n proses waarby die mens self subjektief betrokke is en waar die mens se horison hul verstaan beïnvloed. As historiese wese wíl die mens verstaan; kán die mens verstaan; móét die mens verstaan. Die teologie en die filosofie kom in die benaderings van Von Rad en Gadamer besonder naby aan mekaar en 'n mens vra onwillekeurig die vraag hoe vrugbaar 'n doelbewuste samewerking tussen hierdie twee persone sou gewees het toe hulle nog geleef het. Hoe sou Gadamer se hermeneutiese filosofie Von Rad in sy verstaan van die Ou Testament kon stimuleer en hoe sou Von Rad se verstaan van die Ou Testament Gadamer kon help om die historiese afstand te oorkom?

Dit is duidelik dat die New Proximity between theology and philosophy waarvan Grondin (2002) praat, 'n realiteit is wat ons nie kan ontken nie. 'n Ontkenning van die voordeel van hierdie wedersydse stimulasie sal albei vakgebiede armer maak. Die tyd het aangebreek om ook 'n versmelting van horisonne tussen die filosofie en die teologie te bevorder. Aristoteles het tereg gesê dat beide hierdie vakgebiede te make het met nadenke en die mens se vermoë tot verstaan.

\section{Erkennings}

Die outeurs gee graag erkenning aan en bedank die eksterne resensente wat die konsep artikel gelees het en vir die aanbevelings wat hulle gemaak het.

\section{Mededingende belange}

Die outeurs verklaar dat geen finansiële of persoonlike verhouding(s) hulle beïnvloed het in die skryf van hierdie artikel nie.

\section{Outeursbydraes}

J.H.L.R. (Universiteit van Pretoria) was die promotor en P.H.J.L. (Universiteit van Pretoria) het die navorsing gedoen en die manuskrip geskryf.

\section{Literatuurverwysings}

Blommaert, J., 2005, Discourse, Cambridge University Press, Cambridge. http:// dx.doi.org/10.1017/CBO9780511610295

Brown, G. \& George Y., 1983, Discourse Analysis, Cambridge University Press, Cambridge.

Brueggeman, W., 2001, in G. Von Rad, Theology of the Old Testament - Vol. 1, p. xvi, Westminster John Knox Press, Kentucky.

Crenshaw, L., 1978, Gerhard Von Rad, Word books, Waco.

Derksen, L.D., 1983, On universal hermeneutics, VU Boekhandel, Amsterdam.

Derrida, J., 2001, Foi et Savoir, Seuil, Paris.

Gadamer, H-G., 1989, Truth and Method, 2nd edn. Continuum, New York.

Gee, J.P., 2005, An Introduction to Discourse Analysis: Theory and Method, Routledge, London.

Groenewald, A., 2007, 'Old Testament exegesis: Reflections on methodology', Hervormde Teologiese Studies 63(3), 1017-1031.

Grondin, J., 2002, 'The new proximity between theology and philosophy', in A. Wiercinski (ed.), Between the human and the divine. Philosophical and theological hermeneutics, pp. 97-101, The Hermeneutic Press, Toronto.

Harris, Z.S., 1981, Papers on Syntax, Synthese Language Library, 14, D. Reidel, Dordrecht.

Harris, Z.S., 1991, A Theory of Language and Information: A mathematical approach, Clarendon Press, Oxford.

Jaworski, A. \& Coupland, N. (eds.), 1999, The Discourse Reader, Routledge, London. Johnstone, B., 2002, Discourse analysis, Blackwell, Oxford.

Janicaud, D., 1991, Le Tournant théologie de la phenomenology Française, Éditions d l'Éclat, Combas.

Jünger, E., 1999, Sämtliche Werke, vol. XIX, Klett-Cotta, Stuttgart.

Le Roux, J.H., 1992, 'Once again, methods: A taste of Deistian hermeneutics', in W. Wessels \& E. Scheffler (eds.), Old Testament science and reality: A Mosaic for Deist, pp. 3-19, Verba Vitae, Pretoria.

Le Roux, J.H., 1995, Geskiedenis van die Pentateugnavorsing, Universiteit van Pretoria, Pretoria.

Le Roux J.H., 1996, 'Eksegese is 'n spel', Acta Theologica 16(1), 41-56.

Le Roux, J.H., 2002, 'Gerhard von Rad ' $n$ honderd jaar', Hervormde Teologiese Studies 58(4), 1577-1592.

Loader, J.A., 1986, De structuuranalytische methode, in A.S. Van der Woude (red.), Inleiding tot de studie van het Oude Testament, pp. 128-142, Kok, Kampen.

Longacre, R.E., 1996, The grammar of discourse, Plenum Press, New York.

Rofé, A., 1999, Introduction to the Composition of the Pentateuch, Sheffield Adademic Press, Sheffield.

Schiffrin, D., Deborah, T. \& Hamilton, H.E. (eds.), 2001, Handbook of Discourse Analysis, Blackwell, Oxford.

Stubbs, M., 1983, Discourse Analysis: The sociolinguistic analysis of natural language, Blackwell, Oxford.

Vattimo, G. \& Derrida, J. (eds.), 2001, La Religion, Seuil, Paris.

Von Rad, G., 1967, Old Testament Theology, Vol. 1, Harper \& Row, New York.

Von Rad, G., 2005, From Genesis to Chronicles: Explorations in Old Testament Theology, Fortress Press, Minneapolis.

Weinsheimer, J., 1991, Philosophical Hermeneutics and Literary Theory, Yale University Press, New Haven. 